\title{
Freshwater Crabs of Upper Baleh River, Sarawak
}

\author{
JONGKAR GRINANG*1, YONG MIN PUI ${ }^{1}$, ADI SHABRANI ${ }^{1}$, ANITA MULI $^{1} \&$ \\ CHIEN C. LEE ${ }^{2}$ \\ ${ }^{1}$ Institute of Biodiversity and Environmental Conservation, Universiti Malaysia Sarawak, 94300 Kota \\ Samarahan, Sarawak, Malaysia; ${ }^{2}$ Peti Surat P. 60, Pejabat Pos Pending, 93457 Pending, Sarawak, \\ Malaysia \\ *Corresponding author: gjongkar@unimas.my
}

\begin{abstract}
Freshwater crabs are among the most threatened species, primarily due to their high levels of endemicity, poor dispersal ability, low fecundity and the relatively fragmented nature of freshwater ecosystems. Consequently, regional diversity of freshwater crabs can serve as surrogates for assessing the quality of aquatic habitats in the upper reaches of Baleh River in Sarawak. The six days of sampling during a scientific expedition in the area resulted in the collection of five species of freshwater crabs, including two notable discoveries. The freshwater crabs belong to the families Gecarcinucidae (Arachnothelphusa sp., Bakousa kenepai) and Potamidae (Ibanum aethes, Isolapotamon nimboni, one new genus). The formal description of the new genus and two new species will be made later in appropriate taxonomic journals. The new crab species tends to a specialist in habitat use, being found only from an unusual habitat - a sandy spring within undisturbed forests, near the Elite Honour Camp. These findings indicate that the undisturbed forest patches near the timber camp are important to support population of crabs.
\end{abstract}

Keywords: Decapod crustacean, Gecarcinucidae, Potamidae, semi-terrestrial

Copyright: This is an open access article distributed under the terms of the CC-BY-NC-SA (Creative Commons Attribution-NonCommercial-ShareAlike 4.0 International License) which permits unrestricted use, distribution, and reproduction in any medium, for non-commercial purposes, provided the original work of the author(s) is properly cited.

\section{INTRODUCTION}

Freshwater crabs are among the most threatened species in the tropics, primarily due to their high levels of endemicity, poor dispersal ability, low fecundity and the fragmented nature of freshwater ecosystems. Many species of the world's freshwater crabs have been listed in the IUCN Red List (Cumberlidge et al., 2009). The freshwater crabs of Borneo comprise of 89 known species in 17 genera and three families, many of which are endemic to the region (Grinang, 2016). Over $50 \%$ of the fauna is restricted to Sarawak, and the high diversity is thought to be associated with the diverse aquatic habitats in the state, ranging from high elevation streams to completely dark environments inside limestone cave systems. Studies on species richness of freshwater crabs in Sarawak remain at a state of infancy, and therefore, discovery of many new species may expected, in particular, from pristine and/or hitherto unexplored areas. This paper provides species accounts for freshwater crabs currently known from the upper reaches of Baleh River.

\section{MATERIALS AND METHODS}

During a Scientific Expedition to Upper Baleh River in November 2015, surveys of freshwater crabs were conducted at six tributaries of the river and associated intermittent streams and in nearby moist valleys. Crabs were caught by hand during night surveys or along with fish using the electro-shocking technique. Specimens were examined and compared with the known species (Ng, 1988; Ng et al., 2008; Grinang, 2016).

\section{RESULTS AND DISCUSSION}

The six days of sampling effort (20-25 November 2015) in the upper reaches of Baleh River resulted in the collection of five species of freshwater crabs. These belong to the families Gecarcinucidae (Arachnothelphusa sp., Bakousa kenepai) and Potamidae (Ibanum aethes, Isolapotamon nimboni, and a new genus). Two of the freshwater crabs are new to science (i.e. one new genus with one new species, and a new species of Arachnothelphusa), and will be 
published later in an appropriate taxonomic journal. The discovery of the new genus of freshwater crab from Borneo is not surprisingly because taxonomic studies of crustaceans remain incomplete and large areas of the island remain unsurveyed. The survey had also found that the new crab species tends to specialist in habitat use. The species was found at a localised habitat of sandy spring in an undisturbed forest near the Elite Honour Camp. A semiterrestrial crab, Bakousa kenepai was described from Gunung Kenepai in Kalimantan over a century ago (De Man, 1899), therefore the presence of the species recently at several localities in Sarawak, including upper Baleh River is important (see Grinang et al., 2015b; Grinang, 2017). These findings indicate that undisturbed forest patches nearby the timber camp have supported these crab populations. Therefore, protecting the remaining undisturbed forest within the concession areas is crucial for conserving the freshwater crabs and other aquatic organisms in the region.

Species accounts of freshwater crabs recorded from upper Baleh River are provided below.

\section{Family Gecarcinucidae Rathbun, 1904}

Arachnothelphusa new species

Figure 1

Specimen examined. 1 male $(15.6 \times 12.2 \mathrm{~mm})$, moist habitat, logged forest, upper Baleh River, Kapit, Sarawak, coll. YM Pui, 24 November 2015; 1 juvenile $(8.1 \times 5.9 \mathrm{~mm})$, sandy spring, unlogged forest, near Elite Honour Camp, upper Baleh River, Kapit, Sarawak, coll. J. Grinang, 21 November 2015.

Remarks. The tree-hole dwelling freshwater crab, genus Arachnothelphusa Ng, 1991 of Borneo is currently represented by five species, namely A. kadamaiana (Borradaile, 1900) [northern Sabah], A. melanippe (De Man, 1899) [central Kalimantan], A. merarapensis Grinang, Pui \& Ng, 2015 [northern Sarawak], A. rhadamanthysi $\mathrm{Ng} \&$ Goh, 1987 [eastern Sabah] and A. terrapes $\mathrm{Ng}, 1991$ [eastern Sabah]. Grinang et al. (2015a) remarked that distribution of the genus is widespread, thus discovery of additional new species from Borneo can be expected. The two specimens caught from Upper Baleh River agree well with the holotype of genus Arachnothelphusa (see Ng, 1991) in having a transverse carapace with slightly convex surface; long ambulatory legs, especially the merus, being subequal to length of carapace; a male first gonopod (Gl) which is slender, sinuous, the terminal segment is cylindrical, tapered, about one third of total length of $\mathrm{Gl}$; and the length of distal segment of male second gonopod (G2) is less than one quarter the length of the basal segment. The specimens are distinguished from other five known species in having carapace surface covered with rough granules, and there is no cleft separating the orbital angle from the epibranchial tooth (Figure 1) (versus carapace surface covered with rough granules; external orbital angle separated from epibranchial tooth by deep and broad cleft as found in A. merarapensis and A. terrapes; carapace surface smooth, external orbital angle separated from epibranchial tooth by narrow cleft as shown in A. kadamaiana, A. melanippe and $A$. rhadamanthysi) (see Grinang et al., 2015a). The description of the putative new species will be published in an appropriate systematics journal when a more complete series of specimens are available.

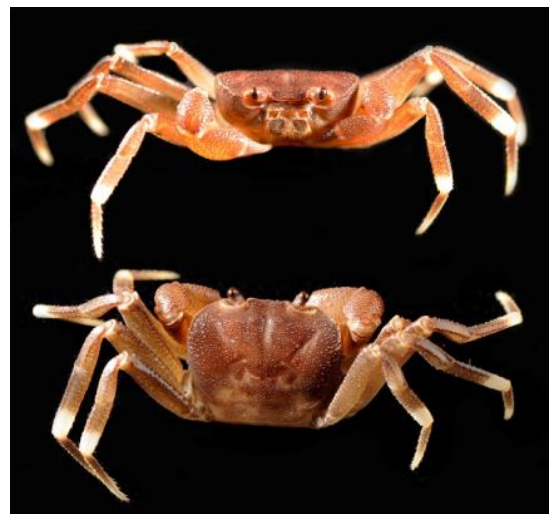

Figure 1. Frontal (top) and dorsal (bottom) views of an undescribed species of Arachnothelphusa (male, $15.6 \times 12.2 \mathrm{~mm}$ ), collected from a moist habitat within a logged forest at upper Baleh River, Kapit, Sarawak.

\section{Bakousa kenepai (De Man, 1899)}

Figure 2

Specimen examined. 5 males (largest $11.4 \times 9.7$ $\mathrm{mm}$ ), 7 females (largest $10.9 \times 9.6 \mathrm{~mm}$ ), sandy spring, unlogged forest, near Elite Honour Camp, upper Baleh River, Kapit, Sarawak, coll. J. Grinang, YM Pui, AS Mohd Ridzuan \& CC Lee, 21 November 2015.

Remarks. The semiterrestrial crab, genus Bakousa Ng, 1995 from Borneo is contains three 
species- B. hendersoniana (De Man, 1899) and B. kenepai (De Man, 1899) from Kalimantan, Indonesia; B. sarawakensis $\mathrm{Ng}, 1995$ from Bako National Park, Sarawak. The present specimens agree with the holotype of $B$. kenepai in having a squarish carapace, very low epibranchial teeth, indistinct postorbital cristae, distinct epigastric cristae with sharp margins, frontal median triangle absent (Figure 2); a G1 which is stout, slightly curving outwards, terminal segment short, cone-shaped; and the G2 with a long distal segment, longer than half length of elongate basal segment. The occurrence of B. kenepai from localities in Sarawak, including upper Baleh River, Gunung Penrissen and Tanjung Datu National Park may indicate that the species is widely distributed across Borneo (Grinang et al., 2015b; Grinang, 2017).

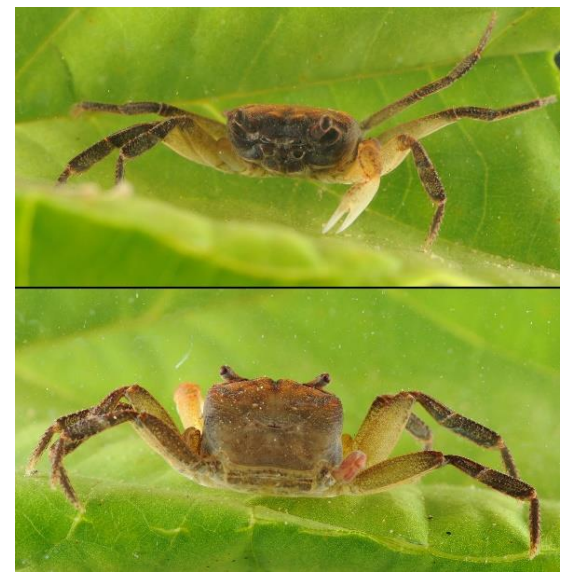

Figure 2. Frontal (top) and dorsal (bottom) views of male, Bakousa kenepai $(11.4 \times 9.7 \mathrm{~mm})$, collected from a sandy spring within an unlogged forest, near Elite Honour Camp, at upper Baleh River, Kapit, Sarawak.

\section{Family Potamidae Ortmann, 1896}

Ibanum aethes $\mathrm{Ng}, 1995$

Figure 3

Specimen examined. 1 male $(16.9 \times 12.1 \mathrm{~mm})$, 1 female $(24.6 \times 17.4 \mathrm{~mm}), 1$ juvenile $(12.8 \times$ $9.1 \mathrm{~mm})$, sandy spring, unlogged forest, near Elite Honour Camp, upper Baleh River, Kapit, Sarawak, coll. J. Grinang, YM Pui, AS Mohd Ridzuan \& CC Lee, 21 November 2015; 1 female $(20.1 \times 14.7 \mathrm{~mm})$, on gravel beach, $\mathrm{Sg}$. Selentang, tributary of upper Baleh River, Kapit, Sarawak, coll. Ayu, 24 November 2015.

Remarks. The semiterrestrial crab, genus Ibanum $\mathrm{Ng}, 1995$ is represented by three
species-I. aethes $\mathrm{Ng}, 1995$ and I. pilimanus $\mathrm{Ng} \&$ Grinang, 2004 from Sarawak; I. bicristatum De Man (1899) from Gunung Liang Koebeng, Kapuas, Kalimantan. It is a small-sized potamid crab with carapace width of adult male rarely broader than $20 \mathrm{~mm}$. The genus is also easily distinguished from other potamid genera in having a very broad male abdomen, stout $\mathrm{G} 1$ and very long G2 (see Ng, 1995a). The present specimens (Figure 3 ) agrees with the descriptions of $I$. aethes in having carapace distinctly rugose (versus carapace smooth in I. bicristatum) and the larger chela of males has no tufts of setae at the base between fingers (versus males having tufts of setae between fingers in I. pilimanus) (see Ng, 1995a; Ng \& Grinang, 2004; Grinang, 2016).

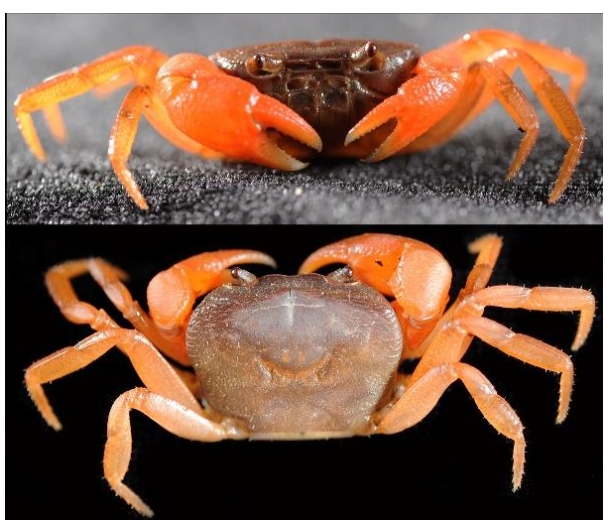

Figure 3. Frontal (top) and dorsal (bottom) views of male, Ibanum aethes $(16.9 \times 12.1 \mathrm{~mm})$, collected from a sandy spring within an unlogged forest, near Elite Honour Camp, in upper Baleh River, Kapit, Sarawak.

\section{Isolapotamon nimboni $\mathrm{Ng}, 1987$}

Figure 4

Specimen examined. 1 male $(33.4 \times 24.9 \mathrm{~mm})$, $\mathrm{Sg}$. Tor, tributary of upper Baleh River, Kapit, Sarawak, coll. A Muli, 22 November 2015; 1 juvenile $(18.4 \times 14.6 \mathrm{~mm})$, Sg. Selentang Kiri, tributary of upper Baleh River, Kapit, Sarawak, coll. A Muli, 22 November 2015; 1 subadult male (released), $1^{\text {st }}$ order stream, unlogged forest, nearby Elite Honour Camp, upper Baleh River, Kapit, Sarawak, coll. J. Grinang, 21 November 2015 .

Remarks. The genus Isolapotamon Bott (1968) is the most speciose freshwater crabs in Borneo, and 14 species are currently known (Grinang, 2016). Of these, seven are found in Sarawak- $I$. bauense Ng, 1987, I. borneense Ng \& Tan, 1998, I. collinsi Holthuis, 1979, I. consobrinum (De 
Man, 1899), I. doriae (Nobili, 1900), I. grusophallus $\mathrm{Ng} \&$ Yang, 1986 and I. nimboni $\mathrm{Ng}, 1987$. The specimens collected from upper Baleh River agree with the descriptions of $I$. nimboni by $\mathrm{Ng}$ (1987), in having a flat surface of carapace; epibranchial tooth low and blunt, separated from external orbital angle by narrow cleft; outer margin of external orbital angle is convex (Figure 4). The species can easily be distinguished from congeners by the thumb-like terminal segment of male G1, with subdistal process subequal to distal process. I. nimboni shows a wide distributional range across Borneo (Grinang, 2016).

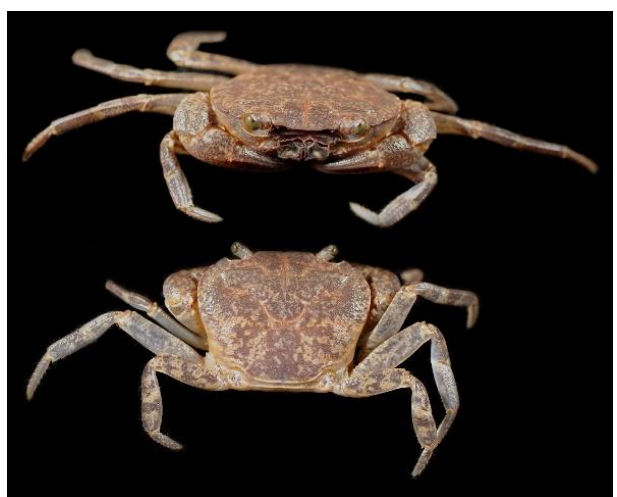

Figure 4. Frontal (top) and dorsal (bottom) views of subadult male, Isolapotamon nimboni, (released), found at a first order stream located within an unlogged forest, near Elite Honour Camp, in upper Baleh River, Kapit, Sarawak.

New genus, new species

\section{Figure 5}

Specimen examined. 3 males (largest $19.6 \times$ $15.5 \mathrm{~mm}), 2$ females (largest $26.7 \times 20.4 \mathrm{~mm}$ ), 1 juvenile $(11.7 \times 9.4 \mathrm{~mm})$, sandy spring, unlogged forest, near Elite Honour Camp, upper Baleh River, Kapit, Sarawak, coll. J. Grinang, YM Pui, AS Mohd Ridzuan \& CC Lee, 21 November 2015.

Remarks. A careful examination of a series of specimens ( 3 males, 2 females and 1 juvenile) showed that they almost certainly represent a new genus. It belongs to the family Potamidae, showing the following familial characters: carapace distinctly broader than long, median frontal triangle absent (Figure 5e), no gap formed when inner margins of merus and ischium are closed (Figure 5c), mandibular palp with single terminal lobe and three articles, and an adult male abdomen which is distinctly triangular (Figure 5c). The new genus can be distinguished from the three known Bornean potamid genera, namely Cerberusa Holthuis, 1979, Ibanum Ng, 1995 and Isolapotamon Bott (1968) in having a very convex carapace with anterior region is directed noticeably down (Figure 5a, b, e), distinctly short ambulatory legs (Figure 5a, b), the male sterno-abdominal cavity reaching all the way to the buccal cavity (Figure $5 c$ ), reduced eyes, with reddish cornea (Figure $5 \mathrm{~g}$ ), and the G1 and G2 elongated with about the same length. It can be further differentiated from Ibanum and Isolapotamon in its lack of flagellum of third maxilliped (Figure 5f) and the inner angle of cheliped carpus is without a tooth (Figure 5a, $\mathrm{b}, \mathrm{g})$.

The new genus is the most striking among the genera in the family Potamidae in having a pink body and legs. The eyes are underdeveloped, with reduced, reddish cornea. Field observation shows that this crab is semi-terrestrial in habit, hiding underneath of moist tree roots and leaf litters. It forages in the larger stream channels during the night.

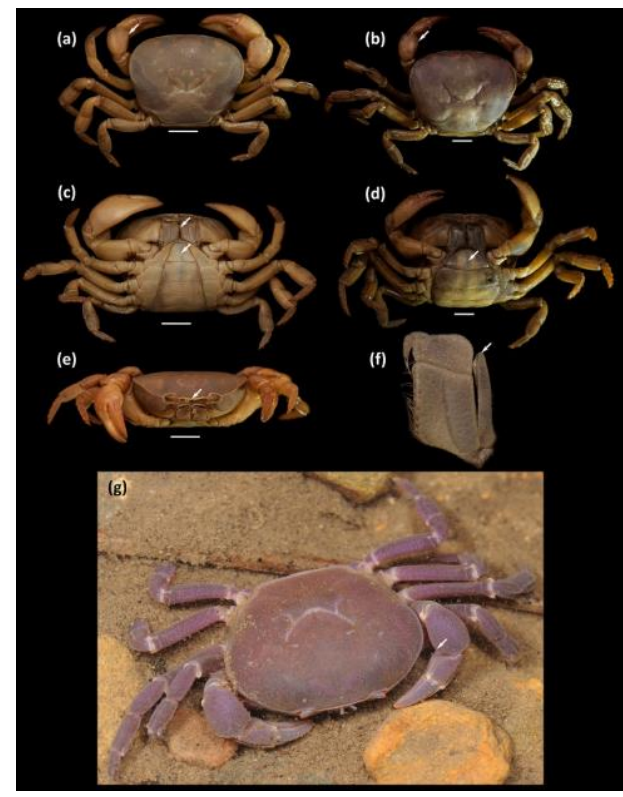

Figure 5. Views of an undescribed potamid crab, male $(19.6 \times 15.5 \mathrm{~mm})(\mathrm{a}, \mathrm{c}, \mathrm{e}, \mathrm{f})$, female $(26.7 \times 20.4 \mathrm{~mm})$ (b, d, g), collected from a sandy spring within an unlogged forest, near Elite Honour Camp, in upper Baleh River, Kapit, Sarawak. a, b, g-dorsal views; c, $\mathrm{d}$ - ventral views showing the male and female abdomens; e - frontal view of male; $\mathrm{f}$ - ventral view of male third maxilliped showing the exopod with undeveloped flagellum. Scale: $\mathrm{a}-\mathrm{e}=5 \mathrm{~mm} ; \mathrm{f}=$ not to scale. 


\section{ACKNOWLEDGEMENTS}

The authors thank Sarawak Energy Berhad for funding this project (GL(I01)/SEB/1B/2013 (13)), Sarawak Forest Department, the Institute of Biodiversity and Environmental Conservation, Universiti Malaysia Sarawak, WTK Timber Company, the staff of Elite Honour Camp, and the Kenyah community in Long Singut in particular Mr. Udau Angie.

\section{REFERENCES}

Borradaile, L.A. (1900). On a small collection of decapod crustaceans from freshwater in North Borneo. Proceedings of the Zoological Society of London, 1900: 93-95.

Bott, R. (1968). Potamiden aus Süd-Asien (Crustacea, Decapoda). Senckenbergiana Biologica, 49: 119-130.

Cumberlidge, N., Ng, P.K.L., Yeo, D.C.J., Magalhães, C., Campos, M.R., Alvarez, F., Naruse, T., Daniels, S.R., Esser, L.R., Attipoe, F.Y.K., Clotilde-Ba, F.-L., Darwall, W., McIvor, A., Baillie, J.E.M., Collen, B. \& Ram, M. (2009). Freshwater crabs and the biodiversity crisis: importance, threats, status, and conservation challenges. Biological Conservation, 142(8): 1665-1673.

De Man, J.G. (1899). Zoological results of the Dutch Scientific Expedition to Central Borneo. The Crustacea. Part II, Brachyura. Notes from the Leyden Museum, 21: 53-144.

Grinang, J. (2016). Taxonomy of freshwater crabs (Crustacea: Decapoda: Brachyura) in Sarawak, Borneo, with autecology of four species (Ph.D. Thesis). Universiti Malaysia Sarawak, Malaysia.

Grinang, J. (2017). Crustaceans. In Mohd-Azlan, J., Tuen, A.A. \& Das, I. (Eds.), Life from headwaters to the coast: Gunung Penrissen roof of western Borneo. Natural History Publications (Borneo) and UNIMAS Publisher. Pp. 95-98.

Grinang, J., Pui, Y.M. \& Ng, P.K.L. (2015a). A new species of tree-hole dwelling crab of the genus Arachnothelphusa Ng, 1991 (Crustacea: Decapoda: Brachyura: Gecarcinucidae) from northern Sarawak, Malaysia, Borneo. Raffles Bulletin of Zoology, 63: 454-460.

Grinang, J., Das, I. \& Pui, Y.M. (2015b). Stream macrofauna. In Rahman, M.A., Tuen, A.A. \& Das, I. (Eds.), Life from headwaters to the coast: Tanjung Datu National Park where Borneo begins. Natural History Publications (Borneo) and Universiti Malaysia Sarawak. Pp. 63-65.
Holthuis, L.B. (1979). Cavernicolous and terrestrial decapod Crustacea from northern Sarawak, Borneo. Zoologische Verhandelingen, 171: 3-47.

$\mathrm{Ng}$, P.K.L. (1987). Freshwater crabs of the genus Isolapotamon Bott, 1968 from Sarawak, Borneo (Crustacea, Decapoda, Brachyura, Potamidae). Sarawak Museum Journal, XXXVII, No. 58 (new series): 139-153. pl. 7.

Ng, P.K.L. (1988). The freshwater crabs of Peninsular Malaysia and Singapore. Department of Zoology, National University of Singapore, Shinglee Press, Singapore, pp. i-viii, 1-156, figs. 1-63, 4 colour pls.

Ng, P.K.L. (1991). Bornean freshwater crabs of the genus Arachnothelphusa gen. nov. (Crustacea: Decapoda: Brachyura: Gecarcinucidae). Zoologische Mededelingen, 65: 1-12.

Ng, P.K.L. (1995a). On one genus and three new species of freshwater crabs (Crustacea: Decapoda: Brachyura: Potamidae and Grapsidae) from Lanjak-Entimau, Sarawak, East Malaysia, Borneo. Zoologische Mededelingen, 69(5): 57-72.

Ng, P.K.L. (1995b). The freshwater crabs and prawns (Crustacea: Decapoda) of Bako National Park, Sarawak, Malaysia, with descriptions of one new genus and three new species. Raffles Bulletin of Zoology, 43 (1): 181-205.

Ng, P.K.L. \& Goh, R. (1987). Cavernicolous freshwater crabs (Crustacea, Decapoda, Brachyura) from Sabah, Borneo. Stygologia, 3(4): 313-330.

Ng, P.K.L. \& Grinang, J. (2004). Decapod crustaceans with descriptions of three new species. In Yong, H.S., Ng, F.S.P. \& Yen, E.E.L. (Eds.), Sarawak Bau Limestone Biodiversity, Sarawak Museum Journal, 59, No. 80 (New Series), Special Issue No. 6: 299-325.

Ng, P.K.L., Guinot, D. \& Davie, P.J.F. (2008). Systema brachyurorum: Part I. An annotated checklist of extant brachyuran crabs of the world. Raffles Bulletin of Zoology, 17: 1-286.

Ng, P.K.L. \& Tan, S.H. (1998). A revision of the Southeast Asian freshwater crabs of the genus Isolapotamon Bott, 1968 (Crustacea: Decapoda: Brachyura: Potamidae). Proceedings of the Biological Society of Washington, 111(1): 52-80.

Ng, P.K.L. \& Yang, C.M. (1986). A new freshwater crab of the genus Isolapotamon Bott, 1968 (Decapoda, Brachyura, Potamidae) from Sarawak, Borneo. Indo-Malayan Zoology, 3: 15-18.

Nobili, G. (1900). Decapodi e Stomatopodi IndoMalesi. Annali del Museo Civico di Storia Naturale di Genova, 40: 473-523. 